\title{
PARALELA/MENTE: «EL REINO INTERIOR» COMO LA «OBRA MAESTRA» DE RUBÉN DARÍO
}

\author{
AlFonso GARCía MORALES \\ Universidad de Sevilla
}

\section{Resumen}

«El reino interior» es el último poema de la primera edición de Prosas profanas (Buenos Aires, 1896) y desde J. E. Rodó hasta la actualidad ha merecido una larga serie de interpretaciones críticas. El objetivo del presente artículo es volver a analizarlo a partir del concepto de «obra maestra», como el poema con el que Darío se propuso conscientemente consagrarse como maestro no sólo de la poesía hispanoamericana sino de la poesía internacional de fin de siglo, a la altura técnica y temática de sus modelos literarios modernos, al nivel de sus propios «raros».

Palabras clave: Rubén Darío, «El reino interior», Prosas profanas, Los raros, magisterio poético, decadentismo, prerrafaelismo.

\begin{abstract}
"The Inner Kingdom" ("El reino interior») is the last poem of the first edition of Profane Hymns (Prosas profanas, Buenos Aires, 1896) and from J. E. Rodó to our days, it has received a wide range of critical analyses. The aim of this article is to re-analyse this poem starting from the concept of "masterpiece", as the poem from which Darío set himself up as a master, not just of the Spanish American poetry, but of the international fin-de-siècle poetry. He managed to be on a par with the techniques and subjects of his literary modern models, and at the same level of his "raros".
\end{abstract}

Keywords: Rubén Darío, “The Inner Kingdom”, Profane Hymns, Los raros, poetic mastery, Decadentism, Pre-Raphaelitism. 
Ya José Enrique Rodó, pese a sus distancias ideológicas con el modernismo rubendariano, calificó «El reino interior» como un ejemplo de «la naturaleza literaria» de Darío y como un «admirable símbolo» de su alma «igualmente sensible a los halagos de la Virtud y a los halagos del Pecado» (1967: 188). Desde entonces la tradición crítica ha vuelto una y otra vez sobre estos dos niveles interrelacionados del poema: por un lado, su destreza técnica y riqueza intertextual extraordinarias, por otro, su escenificación de los irresolubles conflictos morales que parecieron caracterizar la personalidad de Darío. El primer aspecto ha propiciado buen número de estudios, cuya referencia fundamental sigue siendo el libro clásico de Arturo Marasso sobre fuentes literarias y artísticas darianas. El segundo ha hecho que el poema esté siempre presente en las discusiones sobre la religiosidad y sobre el erotismo del escritor y que, por ejemplo, Pedro Salinas lo considerara la más perfecta formulación simbólica de lo que llamó su «erotismo agónico»(1975: 211-212). A esta línea, pero en un sentido diferente, habría que sumar unos pocos y recientes estudios psicológicos y de género que se han arriesgado a ir más allá en la indagación de las ambigüedades sexuales planteadas en el poema.

Mi propósito es volver sobre «El reino interior» aprovechando lo ya hecho pero adoptando una perspectiva fundamentalmente histórica que intente comprenderlo, en la medida en que esto es posible, a partir de los presupuestos desde los que fue escrito y leído en su tiempo. Para ello enfatizaré la función que, creo, el propio Darío le asignó dentro de su proyecto literario. Al titular mi trabajo «Paralela/mente: «El reino interior» como la »obra maestra» de Rubén Darío», empleo «obra maestra» no en un sentido general de magnum opus, de su mejor poema, aunque opino que está entre los mejores, sino en la acepción primera y literal de la expresión: el poema con el que Darío se propuso de manera más evidente acreditarse como maestro, como un maestro no ya de la poesía hispanoamericana sino de la élite poética internacional de fin de siglo, a la altura formal y temática de sus más relevantes modelos modernos, al nivel de sus propios raros de entonces.

Para apreciar esta función es preciso contextualizarlo, volver a marcar el lugar y el momento - en sí mismos estratégicos, significativos- de su publicación. «El reino interior» es el último poema de la primera edición de Prosas profanas y otros poemas (Buenos Aires, Imprenta de Pablo E. Coni e hijos, 1896); ocupa por sí solo la sección final y, a diferencia de la mayoría de las composiciones, no se conocen publicaciones anteriores en prensa (Mejía Sánchez, 1985: X-LXIII; Zuleta, 1989: 183-186; Barcia, 1996: 16-19). Es casi seguro que, aunque lo fue gestando desde antes, Darío lo terminó muy al final 
y que lo reservó para reforzar su impacto y el del libro en los lectores de la época.

Prosas profanas es el poemario con el que Darío vuelve a presentarse tras el ya legendario pero algo lejano y anticuado Azul..., es el fruto de su paso por París y de su estancia en Buenos Aires, el libro paralelo a la colección de artículos Los Raros, la demostración de su modernidad, cultura y técnica poéticas, de su sincretismo creador, la respuesta a quienes habían empezado a cuestionar su primogenitura y liderazgo modernista, la prueba de que su iniciación, al menos su aprendizaje en las nuevas corrientes literarias y su conocimiento del oficio de poeta han concluido. $\mathrm{Y}$ «El reino interior»es, a su vez, el poema de Prosas profanas que termina exhibiendo estas características de forma más deliberada, brillante, insólita y provocativa, llevándolas hasta el virtuosismo, casi hasta el juego, en un alarde de conocimientos y facultades, de citas y homenajes, de guiños a los entendidos e ironías a los contrarios, que no excluyen algo de autoironía y mucho de delicadeza y originalidad.

Por su importancia en el orden final del poemario, un orden más acumulativo e impuesto que planificado u orgánico, y por su culturalismo, «El reino interior» puede vincularse especialmente al poema de apertura, el dieciochesco «Era un aire suave...», y más aún al otro poema unisección, el también tardío, el ambicioso y mitológico «Coloquio de los Centauros». Son los tres grandes «paisajes de cultura» de la colección —el neorrococó, el neopagano y el neomedieval o prerrafaelita—, ejemplos de que en Darío lo muy moderno suele ir unido a lo muy antiguo, y escenarios adecuados para desplegar sus representaciones del erotismo y sus autorrepresentaciones como poeta: en estos casos, la de poeta aristocrático y melancólico, la de poeta iniciado en los misterios del universo (incluyendo el misterio del sexo) y la de poeta doblemente atraído por la espiritualidad y la sensualidad. Concretamente esta última imagen de escritor entre pagano y cristiano que Darío cultivó con insistencia desde entonces, respondió no solo a motivaciones biográficas sino históricas y literarias. Era expresión de las incertidumbres, deseos y temores de una época en que la secularización ponía en crisis la moral sexual tradicional y las categorías asentadas de lo sagrado y lo profano. Y era una postura pública de artista consciente y desafiantemente moderno. Con ella Darío estaba identificándose hasta cierto punto con Verlaine, de hecho el artículo necrológico y el famoso «Responso» al «padre y maestro mágico» de simbolistas y raros se basan en el mismo paralelamente moral de «El reino interior»; y al mismo tiempo estaba reclamando tácitamente merecer la condena/ consagración de Max Nordau, el raro contrario a los raros, para quien uno de los síntomas 
mayores de la degenerada literatura de su tiempo era precisamente el misticismo profano, la mezcla constante de fervor religioso y fervor sensual.

Y una observación sobre el prerrafaelismo. Desde su redescubrimiento en los años 60 del siglo XX y, más concretamente, desde el pionero estudio de Francisco López Estrada Rubén Darío y la Edad Media (1971) se ha reconocido la importancia de esta singular corriente artística en Darío, pero queda realmente mucho por investigar sobre la manera en que éste la conoció, interpretó e integró en su mundo literario. Solo diré que creo que la asimiló tarde, a través de Francia, ya mezclada pero nunca confundida del todo con el decadentismo, y que supo percibir y aprovechar su ambigua relación con éste, su conflictiva modernidad antimoderna, su híper-refinado ingenuismo. Como dijo el teórico de la modernidad estética Matei Calinescu, «la fascinación por la decadencia y la fascinación aparentemente contradictoria por los orígenes y el primitivismo son realmente dos caras de un mismo fenómeno» (1991: 161). Esas dos caras — tradicional y moderna, cristiana y pagana, sagrada y profana - están estrechamente unidas y al mismo tiempo separadas en Prosas profanas y muy especialmente en el prerrafaelita y decadente «El reino interior».

La complejidad del poema, sus dualismos y propósitos, aparecen cifrados en el paratexto. El sugerente título «El reino interior» alude a esa otra realidad más intensa y profunda con la que soñaron los modernistas, la de la belleza y el espíritu, contiene el esteticismo idealista, el aristocratismo espiritual y el medievalismo fantástico que animan el poema, concepciones opuestas a las que rigen en el reino exterior, burgués, de lo realista y lo contemporáneo ${ }^{1}$. La dedicatoria y el epígrafe nombran dos «raros» con los que Darío se identificó y mediante los que afirmó su modernidad cosmopolita, su pertenencia a la hermandad internacional de escritores nuevos. «A Eugenio de Castro», jefe del simbolismo en Portugal, solo dos años mayor que él pero ya reconocido en Francia (Fein, 1958: 555-561; 1967: 359-365). En octubre de 1896, mientras Los raros y Prosas profanas estaban en prensa, en el homenaje que el Ateneo de Buenos Aires ofreció a Darío, uno de los hitos de su «campaña» argentina,

1. La imagen, en la que puede percibirse un eco de Le Regne du silence (1891) de Georges Rodenbach, aparece, tal vez poco antes del poema, en «Palabras liminares» de Prosas profanas, cuando el poeta, desdoblado en la figura de Silvano, habla de su reino interior o bosque ideal: »cierra los ojos y toca para los habitantes de tu reino interior. ¡Oh pueblo de desnudas ninfas, de rosadas reinas, de amorosas diosas!» (Darío, 1967: 547). Su contrario literal reaparecerá en el poema «Aguas claras», que los editores Méndez Plancarte y Oliver Belmás consideran de atribución dudosa y fechan hacia 1914: «Pero eso no me basta... Me siento comprimido/ en un Reino Exterior tan corto y comprimido» (Darío, 1967: 1097). 
éste leyó la conferencia «Eugenio de Castro y la literatura portuguesa», que se publicó en La Nación y aún tuvo tiempo de incluir como capítulo final en Los raros. En ella comparó a Castro con D'Annunzio, ambos formaban parte de lo que llamaba el «renacimiento latino», al que debía unirse el modernismo hispanoamericano para de esta forma integrarse en el movimiento internacional del Arte nuevo. Un movimiento del que entonces no participaba la rezagada España.

La cita «... with Psychis, my soul» procede del poema «Ulalume», del escritor, del mito Edgar Allan Poe, a quien Darío retrató como un Ariel nacido en un país de Calibanes. Es una cita algo alterada y bastante descontextualizada (Barcia 1996: 35-36), como adelantando las apropiaciones y combinaciones atrevidas, pero siempre respetuosas, que hará del archivo y el museo occidental, pero que contiene el tema y la protagonista esenciales del poema: el desdoblamiento del poeta y su alma, la personificación de ésta en una frágil figura femenina.

Inmediatamente traspasado el umbral, Poe y Castro se unen a un tercer e insospechado raro, Fra Doménico Cavalca: «Una selva suntuosa / en el azul celeste su rudo perfil calca. / Un camino. La tierra es de color de rosa, / cual la que pinta fra Doménico Cavalca / en sus Vidas de santos» (Darío, 2011: 382$385)^{2}$. Fra Doménico era un olvidado hagiógrafo del Trecento italiano. Darío, en una búsqueda de la poesía de lo primitivo impulsada por el prerrafaelismo, rescató y glosó su obra Vite scelte dei Santi Padri en un artículo de 1894 que más tarde, en un gesto conscientemente paradójico de modernidad, incluyó dentro de Los raros. La imagen que importa destacar ahora es «cual la que pinta fra Doménico Cavalca». Es una imagen que está ya en su artículo: en las obras de Cavalca, se dice allí, «brilla la luz sencilla y adorable, la expresión milagrosa de las pinturas de Botticelli»; como un monje iluminador, dibuja «los paisajes más ideales, las flores más poéticamente sencillas que podáis imaginar» (Darío, 2015: 237, 240). Pero aquí se convierte en clave para la configuración e interpretación del poema. Darío introduce una buscada confusión entre la literatura y la pintura (sabe bien que un lector inadvertido tomará a Fra Doménico por un pintor, que posiblemente lo asociará a los pintores religiosos como Giotto o Fra Angélico), y con ello introduce una nueva identificación: Fra Doménico es un escritor que pinta como él mismo es capaz de hacerlo y como, de hecho, va a hacer en su poema.

2. A partir de ahora todas las citas del poema se harán, sin indicación de página, a partir de esta edición.

Anales, 28 (2016), pp. 99-117 
Desde su transformación chilena, desde Azul..., Darío adoptó el ideal de la integración o unidad de las artes y experimentó con técnicas de literatura fusionista como parte de su obra de renovación. En «El reino interior» muestra el progreso alcanzado, e inspirado en el paralelismo entre pintura y poesía del prerrafaelismo, ofrece el más completo y sofisticado ensayo de trasposición que, creo, hizo nunca. Proporciona al lector una experiencia imaginaria de espectador de un cuadro, logrando no sólo impresiones psicológicas de color y de línea, sino algo más difícil: sutiles efectos de perspectiva y aun de simultaneidad. La misma disposición tipográfica —las separaciones mediante asteriscos junto con las tiradas de versos calculadamente repartidas- cumple una función: crea la ilusión de sincronismo, hace que la estructura total del poema sea análoga a la de una serie articulada de cuadros, esto es, a la de un políptico o retablo, uno de los formatos característicos del arte religioso. Cada una de las secciones, descriptivas pero hiladas narrativamente, trabajadas independientemente pero subordinadas al conjunto, corresponderían con relativa exactitud a las distintas tablas: las de las Virtudes y los Pecados a los grandes paneles centrales, la del escenario al inferior o superior, y las del alma princesa que se asoma y se aleja de la ventana a los laterales o portezuelas. Darío ha titulado atrevidamente su libro Prosas profanas, en «Palabras liminares» lo ha comparado con «la misa rosa de mi juventud», con una iglesia de «vidrieras historiadas» en la que se realiza una liturgia erótica (Darío, 2011: 325-326). No es inconsecuente metafórica o arquitectónicamente que coloque al fondo del poemario este «re-tablo» (literalmente: lo que está detrás del altar) en el que también celebra lo religioso y lo profano simultáneamente.

En la primera parte Darío presenta una estampa minuciosa, decorativa y simbólica, tal como concibe el paisaje de los primitivos. Subraya las líneas («perfil», «calcar»), destaca los colores simbólicos —azul, rosa- de los por sí arquetípicos selva, cielo y camino, y utiliza el impersonal del verbo ver para inducir la visión imaginativa e introducir los detalles: «se ven extrañas flores/ de la flora gloriosa de los cuentos azules,/ y entre las ramas encantadas (...)». El pasaje deriva de Cavalca o de su glosa de Cavalca³. En él actúa también la

3. Cuando resume el relato que hace Cavalca del viaje de tres monjes en busca del Paraíso terrenal, escribe: «Arriba estrellas, más radiantes que las que vemos en el cielo: -sol, árboles, frutas y flores y pájaros mejores que los nuestros; y este precioso detalle: 'la terra medesima é dall'uno lato bianca como neve e dall'altro rosa'» (Darío, 2015: 246). Monguió observó que en la cita en italiano Darío transcribe mal «rosa» por «rossa», y que de ahí procede el adjetivo del poema: «desdeñando la diferencia entre $s$ y ss, entre s sonora y sorda en italiano, Darío tradujo rossa no por roja sino por rosa; y hay que confesar que si se equivocó léxicamente, poéticamente, como de costumbre, estuvo acertado» 
reminiscencia de los libros iluminados, con sus mayúsculas historiadas en las que se entrelazan motivos florales y zoomórficos. Pero observados de cerca esta flora y estos pájaros, gloriosos o celestes y al mismo tiempo extraños, adelantan la ambigüedad entre lo espiritual y lo carnal, y combinan lo ingenuo y ultrarrefinado con una ironía que culmina en el paréntesis explicativo final:

y entre las ramas encantadas, papemores cuyo canto extasiara de amor a los bulbules.

(Papemor: ave rara. Bulbules: ruiseñores).

En Historia de mis libros Darío explicó: «En 'El reino interior' se siente la influencia de la poesía inglesa, de Dante Gabriel Rossetti y de algunos de los corifeos del simbolismo francés», y aclaró, también entre paréntesis, como eco del propio paréntesis del poema: «(¡Por Dios! ¡Si he querido en un verso hasta aludir al 'Glosario' de Plowert!...)»(1950-1955, 1: 212). Se refiere al Petit Glossaire pour servir à l'intelligence des auteurs décadents et symbolistes (1888) compilado por Jacques Plowert, pseudónimo de Paul Adam -a quien dedicará un artículo en la segunda edición de Los raros- y Félix Fénéon. Este breve diccionario paródico, surgido al calor de las polémicas literarias francesas, contiene definiciones ejemplificadas de los neologismos que supuestamente invadían la escritura de decadentes y simbolistas. Allí aparece «papemor» definido a partir de la poesía de Jean Moréas, otro raro esencial, como «oiseau fabuleux» (Marasso, 1954: 143). Lo importante es que Darío no solo captura y hace suyas esas palabras inusitadas sino que lo hace con el mismo gesto entre insolente y defensivo, irónico y autoirónico de Plowert. Con su paréntesis responde burlonamente a las acusaciones de la crítica antimodernista que tachaba el lenguaje de los nuevos, su lenguaje, de incomprensible, y sin dejar de reconocer el carácter extremado, incluso excesivo de este lenguaje, también recuerda su función enriquecedora, su capacidad de romper con clisés y expresar bellamente nuevas ideas y matices. Poco después Lugones continuará a Plowert y a Darío con su Diccionario portátil para simbolistas, dirigido a «los que no comprendían», tanto a los antimodernos como a los modernos falsos, seguidores del simbolismo por simple moda.

Merece notarse el uso que Darío hace aquí del paréntesis poético, comparable por su delicada efectividad a los de otros momentos de su madurez creativa. Como cuando en «Palabras liminares» de Prosas profanas introduce entre sus grandes admiraciones su «fervor cordial» por Verlaine: «Después

(Monguió, 1968: 725). Años después, comentando el cuadro «Flora» de la prerrafaelita tardía Evelyn Morgan, Darío también hablará de »la singular detallada flora de los primitivos, las flores decorativas» (en López Estrada, 1981: 193-194; y Darío, 2006: 178). 
exclamo: ¡Shakespeare! ¡Dante! ¡Hugo!... (Y en mi interior: ¡Verlaine...!)» (Darío, 2011: 326); como cuando en Cantos de vida y esperanza cierra los sonetos «Caracol»: «(El caracol la forma tiene de un corazón)», y «La dulzura del ángelus...»: «( $¡$ Oh, suaves campanas entre la madrugada!») (Darío, 2011: 462, 437); o como cuando en «A Roosevelt» señala como contrapeso al poderío norteamericano las promesas de los emergentes Chile y Argentina: «(Apenas brilla, alzándose, el argentino sol / y la estrella chilena se levanta...)» (Darío, 2011: 421). Todos, y especialmente este de papemores y bulbules, tan poéticamente metapoético, están dirigidos, como él dijo, a expertos catadores "de elixires intelectuales», «de sutiles pensares y de gentilezas de estilo» (Darío, 1950, 1: 111).

Establecido el fondo, se presenta el personaje: «Mi alma frágil se asoma a la ventana obscura / de la torre terrible en que ha treinta años sueña». El dualismo alma-cuerpo se representa en una imagen de «cuento azul» medievalista tempranamente trabajada por Darío: la princesa prisionera y soñadora dentro del castillo paterno. Los antecedentes más próximos son el cuento «La princesa Psiquia» y sobre todo el poema «Sonatina» (Rull, 1965: 33-50; 1998: 323-336). La insatisfacción, soledad, hastío, spleen o como quiera llamarse esa «tristeza» indefinida de la princesa de «Sonatina» está relacionada con el estado de ánimo de la protagonista de «El reino interior», quien tampoco participa del todo de la exultante Primavera, cuya sonrisa y canto ocultan un conflicto interior.

Me detengo en los versos «Y las manos liliales agita, como infanta / real...». El tratamiento de la princesa como «infanta» tiene un matiz arcaizante, un matiz españolizante (tal vez el único en el poema), y al mismo tiempo, un sentido moderno. Como no dejarían de percibir los contemporáneos más al día, remite a modo de homenaje a Au jardin de l'Infante (1893), la opera prima de Albert Samain, admirada por los maestros del simbolismo, también precedida por unos versos de Poe y que comienza con un melancólico poema («Mon âme est une infante en robe de parade») sobre el alma orgullosa y resignada en el encierro de su Escorial. Además, la palabra «infanta» se adecua a la supuesta ingenuidad de la estética prerrafaelita, y subraya el infantilismo que se atribuye a la princesa pese a sus «treinta años». Esto último cabría entenderlo en sentido autobiográfico, como leve refuerzo a la hipótesis de que el poema se hubiera escrito poco antes de cerrarse el libro, cuando Darío cumplió exactamente treinta años, incluso como una alusión al carácter de «niño grande» con el que el propio Darío y muchos de sus contemporáneos y biógrafos posteriores explicaron su psicología irresoluta y vulnerable. 
En cuanto a «manos liliales», Darío encontró asociadas la mano virginal y el lilium candidum en muchos lugares: en las Anunciaciones primitivas, en el verso virgiliano que Dante oye de boca de Beatriz en su Purgatorio (Manibus o date lilia plenis), en el cuadro «Ecce ancilla Domini» y en el poema y la pintura «The Blessed Damozel» de Rossetti... El neologismo «lilial» lo usó, seguramente por primera vez, hablando de las heroínas de Poe, de la procesión de «las liliales vírgenes cantadas en brumosa lengua inglesa por el soñador infeliz, príncipe de los poetas malditos» (Darío, 2015: 113). Y lo desarrolló en el poema que poco después publicó con el título «Lilial», dedicado a su primera esposa fallecida, Rafaela Contreras, alma «hermana» de las mujeres muertas de Poe. «Lilial», que contiene muchas imágenes de «El reino interior», pasó a llamarse en Prosas profanas «El poeta pregunta por Stella». Un título más hermoso y acaso más prudente. Darío sabía la reacción que la palabra «lilial» causaba en los antimodernistas, que pronto, sobre todo en España, la considerarían el epítome del neologismo inadmisible, de la cursilería ridícula, cuando no directamente, para usar el término homofóbico, de la «mariconería» poética. Son conocidas las mofas de Madrid Cómico — los «memo-liliales» de Clarín, las «Lilialerías» de Tomás Carretero, la parodia «Lirios abstractos, para mi amigo de las entrañas Floro Mariquítez» de Juan Pérez de Zúñiga一, a las que Maeztu respondería: Clarín y compañía no comprendían que «las manos liliales, las torres ebúrneas» de los nuevos poetas americanos no eran frivolidades, tontadas, sino que expresaban como un «anhelo indefinido, como un vago vislumbre de otra literatura, como un preludio cuatrocentista de un renacimiento» (en Lozano, 1978: 64).

El poeta se desdobla y ve a su alma en forma de princesa, a su vez ésta se desdobla y desde la torre contempla su propio interior objetivado en dos comitivas que marchan por ambos lados del camino: una de doncellas como descendidas del azul celeste, que encarnan las virtudes, otra de mancebos como salidos de la selva suntuosa, que encarnan los vicios. «Me parece de un efecto supremo — comentó Rodó- la oposición de esos dos cuadros» (1967: 188). Y en efecto, esas dos descripciones a modo de cuadros o, decíamos, de hojas centrales, de díptico casi independiente del resto del retablo, representan dos visiones, dos grupos de figuras en perfecto equilibrio y contraste, a los que se asignan un concreto sentido alegórico. Salinas fue el primero en caracterizar «El reino interior» como Psychomachia, en referencia al poema latino de Prudencio que representó literalmente las «batallas por el alma del hombre» entre virtudes y vicios personificados, la obra modelo del arte alegórico medieval (Salinas, 1975: 273; López Estrada, 1971: 134). 
La primera descripción comienza con la pregunta «¿Qué son se escucha, son lejano, vago y tierno?», que facilita la transición, crea expectativa y suscita, mediante insinuaciones de distancia, el efecto psicológico de perspectiva. El lector imagina ver surgir y acercarse desde la hondura a las siete princesas (Chasca, 1974: 282). En poemas anteriores Darío había utilizado exactamente el mismo procedimiento para describir grupos de figuras en movimiento: primero introduce las referencias acústicas, después las visuales, con lo que sugiere cinéticamente su aproximación y visualización gradual. Así en el cortejo de «Marcha triunfal» ( «iYa viene el cortejo! / ¡Ya viene el cortejo! Ya se oyen los claros clarines. / La espada se anuncia con vivo reflejo;/ iya viene, oro y hierro, el cortejo de los paladines! // Ya pasa, debajo los arcos...» Darío, 2011: 427); así en la procesión báquica de «Friso» y sobre todo en la soberbia introducción musical y escultórica del «Coloquio de los Centauros». En esta última hace un uso remarcadamente expresivo de los encabalgamientos bruscos de los versos, acompañando al cabalgar rítmico de la manada de monstruos que se acerca («Son los centauros. Cubren la llanura. Les siente / la montaña. De lejos forman son de torrente / que cae; su galope al aire que reposa / despierta, y estremece la hoja de laurel-rosa»), y que se detiene congelándose como un conjunto diferenciado de estatuas: («Son los centauros. Unos enormes, rudos; otros / alegres y saltantes como jóvenes potros; / unos con largas barbas como los padres-ríos; / otros imberbes, ágiles y de piafantes bríos, / y de robustos músculos, brazos y lomos aptos/ para portar las ninfas rosadas en los raptos» (Darío, 2011: 351). Este uso se aplica en «El reino interior» más suavemente al caminar también cadencioso, como de ballet casi flotante de las vírgenes: «Por el lado derecho del camino, adelanta / el paso leve una adorable teoría / virginal». Por el lado derecho implica que debe haber un lado izquierdo, crea una tensión, un paralelismo que no se completa psicológica, visualmente hasta el fragmento siguiente. Adelanta / el paso: Darío llega al grado de sugerir una sugerencia pictórica: el efecto de «trampantojo»o ilusión óptica, de figuras que parecen salirse del marco, aplicado a los pies de las vírgenes que avanzan. Teoría virginal: uno de los significados de «teoría», frecuente en el aristocrático léxico modernista, es, tal como recoge el DRAE, «procesión religiosa entre los antiguos griegos», con lo que se insinúa que lo cristiano no velará por completo lo pagano de estas vírgenes.

Y siete blancas doncellas: a partir de aquí la transposición se centra en crear literariamente el blanco. Siguiendo el ejemplo del poeta-pintor Gautier y de su impecable «Symphonie en blanc majeur», los modernistas realizaron frecuentes ejercicios poéticos de colores, con cierta predilección por el blanco. Darío escribió «Blasón», «Bouquet», el mencionado «El poeta pregunta por 
Stella» o «En elogio del Ilmo. Sr. Obispo de Córdoba Fray Mamerto Esquiú, O. M.». Los antimodernistas tampoco dejaron de escandalizarse (un miembro del Ateneo de Córdoba dimitió al oír la sinestesia «blanco horror de Belcebú» en el elogio a Esquiú) ni de hacer de esta práctica el blanco de sus sátiras: «Pero yo soy un artista monócromo — se burlaba Clarín-. ¡Todo blanco! Hace muchos años escribió Tomás Tuero: ¡Todo azul! (antes que Rubén Darío). Pues yo digo: ¡todo blanco!... este es el arte modernista ¡La mono...tonía, la mono...manía!» (en Lozano, 1978: 159). En «El reino interior» Darío refina e integra el procedimiento. Consigue la impresión monocroma acumulando sugestiones en un hábil entramado de imágenes poéticas y de referencias culturales. No entro en las comparaciones y metáforas que empiezan con las doncellas como rosas cubiertas del rocío de la mañana: «Siete blancas doncellas, semejantes/ a siete blancas rosas de gracia y de harmonía/ que el alba constelara de perlas y diamantes». Tampoco en cómo esas imágenes insisten en la belleza espiritual pero no dejan de transparentar la belleza corporal. $\mathrm{Y}$ apenas me detengo en cómo esas imágenes monocromáticas encadenadas van acompañadas por toda una serie de repeticiones y variaciones eufónicas, de lo que Pedro Luis Barcia llama «leves juegos de trenzado y enlace» fonético (1996: 45-46): iteración de palabras homófonas, derivadas, concatenadas, rimas internas, rimas en el mismo verso («alabastros celestes habitados por astros») y paronomasias: «sus vestes son tejidas del lino de la luna». Sí habría que recordar que estos artificios tuvieron en su momento un sentido provocativo. Darío sabía que Max Nordau en Entartung (1892) los consideraba un síntoma morboso del carácter degenerado de los nuevos artistas, una enfermedad mental diagnosticada como «ecolalia», propia del habla de los imbéciles, que afectaba a prerrafaelitas y simbolistas, a Rossetti y Verlaine. Darío contestó a esto en el artículo que dedicó a Nordau y que con tanta ironía incluyó en Los raros - Nordau era, al menos, tan raro como los raros a los que unánimemente condenaba-, pero también llevando a la práctica la «ecolalia» en distintos poemas: aquí con el «lino de la luna», precedido de «la torre terrible» o seguido de las «dulces delicias de los cielos» ${ }^{4}$.

4. En su capítulo sobre los prerrafaelitas Nordau decía que «esta singularidad del lenguaje de los idiotas y de los dementes - la ecolalia - la hallamos con frecuencia en Rossetti; he aquí algunas muestras: "So wet she comes to wed?" — "iTan mojada viene a la boda?" (Stratton water). El sonido wed ha llamado al sonido wet. En el poema My sister's sleep, leemos en un trozo que se trata de la luna: "The hollow halo it was in -Was like an icy cristal cup" - "El círculo hueco en el cual estaba la luna parecía una copa de cristal helado". Es manifiestamente absurdo (...) pero la asonancia ha juntado 'hollow' a 'halo'» (Nordau, 1902: I, 146-147). Estos wet-wed o hollow-halo lunar no son diferentes a la torre terrible o al lino de la luna, al culto oculto o a los delirios de las liras de Darío.

Anales, 28 (2016), pp. 99-117 
Entre las alusiones culturales hay una primera y directa: «Tal el divino Sandro dejara en sus figuras,/ esos graciosos gestos en esas líneas puras». Si el «divino Watteau» y su «Embarque para Citerea» fueron para Darío iconos de la estética dieciochesca, el «divino Sandro Botticelli» y su «Alegoría de la Primavera» representaron la estética prerrafaelita. Ahora bien, Darío evolucionó en su visión de Botticelli. En principio lo consideró un pintor medieval e ingenuo, el correlato de Fra Doménico Cavalca, una consideración anacrónica, muy parcial, que hasta cierto punto mantiene en el poema, pero que a partir de la elaboración de éste empezó a cambiar. Más tarde, en las crónicas de su visita a Italia,-cuando contempló directamente sus obras, llegó al extremo contrario de presentarlo como un «exquisito y raro»: «no es de los que serenan» dirá, no es como «el seráfico Fra Angélico» sino como Baudelaire, de los que trajo un estremecimiento nuevo y hasta enfermizo al arte (Darío, 1950: 3 , 597-598). Respecto al aprovechamiento que hizo de «La Primavera», un cuadro complejo pero evidentemente más pagano o renacentista que medieval, Marasso propuso una interpretación curiosa: La Primavera habría ofrecido a Darío el modelo inicial, pero éste la transformó y disoció, utilizando Las Gracias para las Virtudes y el Mercurio para los Pecados (1954: 139). Es una explicación que no se puede descartar, pero los estudiosos suelen priorizar como fuente otro cuadro: «The Golden Stairs» (1880) del maestro del segundo prerrafaelismo Edward Burne Jones. Darío admiró a este platónico y melancólico pintor, «delicado y arcaico, flotante en un mundo de visiones legendarias, o en la dulce luz de un maravilloso paganismo», que ofrecía «el imán insólito de sus mujeres singularmente expresivas y fascinantes» (1950: 3, 418), si bien, en último extremo, «seguidor, genial pero seguidor» de Botticelli (2006: 177). Y parece que trasladó a su descripción mucho de "The Golden Stairs», un cuadro de formato alargado y factura monocroma, onírico y preciso, con su escala de figuras casi idénticas, como reflejos de un lejano arquetipo, a través de cuyos drapeados se adivinan los más hermosos desnudos, en el que es evidente cuánto hay de ingenuo y cuánto más de artificioso, de medieval y de clásico, de espiritual y de erótico, de prerrafaelismo original pero también de simbolismo y aún de Art Nouveau.

La segunda comitiva se define por contraste y correspondencia respecto a la primera. Y la palabra que concentra semántica y estructuralmente esta relación es paralelamente: «Al lado izquierdo del camino y paralela-/mente, siete mancebos». Entre la serie de palabras cargadas de especial significado (papemores, infanta, liliales...), ninguna tan marcada como esta. No es un paralelamente cualquiera, es el título que el mismísimo Paul Verlaine usó en el poemario Parallèlement para expresar su conflicto entre el vicio y la virtud. 

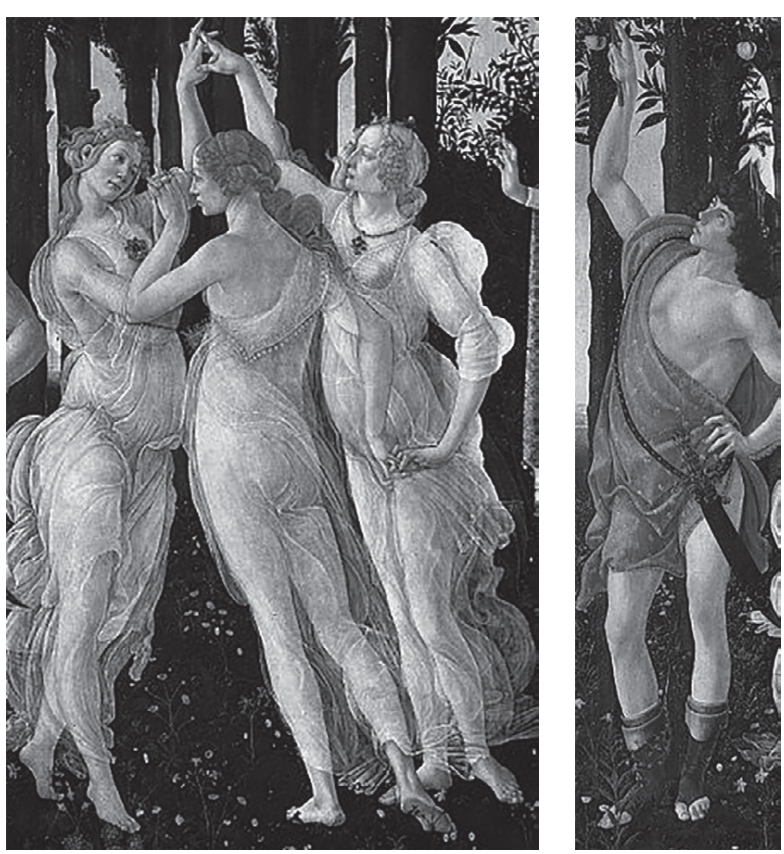

Sandro Botticelli: La Primavera. Detalles de Las Gracias y del Mercurio.

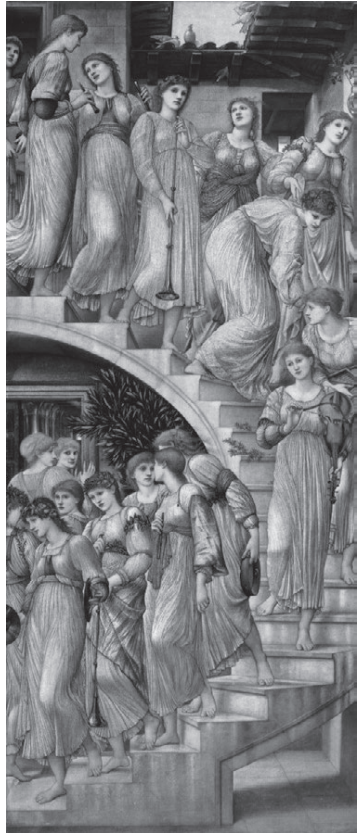

Edward Burne-Jones:

The Golden Stairs, 1880.

Un título que, tal como explicó Darío, ya había inspirado su «Responso»: «El "Responso" a Verlaine prueba mi admiración y fervor cordial por el "pauvre Lelian', a quien conocí en París en días de su triste y entristecedora bohemia, y hago ver las dos faces de su alma pánica: la que da a la carne y la que da al espíritu; la que da a las leyes de la humana naturaleza y la que da a Dios y a los misterios católicos, paralelamente» (Darío, 1950: 1, 211). Y entre la serie de recursos técnicos desplegados, ninguno tan virtuoso, tan efectista y lleno de significado como este de destacar esa misma palabra haciendo recaer en ella el encabalgamiento. Estamos ante uno de los raros encabalgamientos léxicos, lo que se conoce como «tmesis» o corte, tal vez el más acertado de la historia de la poesía en español ${ }^{5}$. Si «El reino interior» tiene un «valor de posición»

5. Barcia (1996: 44) advirtió que no es un fenómeno nuevo ni exclusivo del modernismo, y recordó algún ejemplo de Fray Luis de León ( «Y mientras miserable-/ mente se están los otros abrasando» de la célebre «Oda a la vida retirada») y un par de usos posteriores del propio Darío: «El alma que se advierte sencilla y mira clara-/mente la gracia pura de la luz cara a cara»; «En lo alto del mástil una guitarra había/ como en el viaje de D’Annunzio y tan sutil-/mente cantaba amable esa cigarra mía» (1967: 667 y 1139). 
(Barcia 1996: 58) especial dentro de Prosas profanas, «paralela-/mente» lo tiene dentro de «El reino interior». Podríamos compararlo con la espectacular y conocida (o)posición fonética, semántica y estructural de los monosílabos «No» y «Dios» de la «Oda a Roosevelt». «Paralela/mente» es, para volver a la analogía espacial y pictórica, el quicio o la bisagra sobre el que giran las dos hojas del retablo, es tanto la ruptura como la ligazón entre las santas y los satanes, la articulación entre lo sagrado y lo profano, entre el misticismo y el erotismo, entre lo prerrafaelita y lo decadente.

Si la parte dedicada a las princesas prerrafaelitas nombra al «divino Sandro», ahora la dedicada a los príncipes decadentes remite —en un vaivén más entre lo pictórico y lo literario, lo antiguo y lo moderno- a Verlaine: «hermosos, parecidos/ a los satanes verlenianos de Ecbatana». Se refiere a "Crimen amoris», que comienza con una fiesta satánica en la legendaria Ecbatana:

Dans un palais, soie et or, dans Ecbatane,

De beaux démons, des satans adolescents,

Au son d'une musique mahométane,

Font litière aux Sept Péchés de leurs cinq sens

(Verlaine, 1962: 378) ${ }^{6}$.

Pero el arte combinatorio de Darío siempre es complejo y opino que sus mancebos son tanto o más «parecidos» que a los satanes verlenianos de «Crimen amoris» al baudelairiano Satán Eros de Le Spleen de Paris ${ }^{7}$. Y en conjunto se

Pero estos mismos ejemplos prueban que, por su función expresiva, el encabalgamiento léxico de «El reino interior» está entre los más acertados de la historia de la poesía en español y que Darío no volvió a emplearlo con el mismo brillo.

6. «Crimen amoris» es un poema filosófico-narrativo en el que Verlaine reflexiona sobre la existencia del bien y del mal para terminar, lleno de culpa, reconociendo como pecado demoniaco y vano de orgullo intentar ir más allá de las categorías morales. Pero aparte de parafrasear su primera estrofa y de incorporar para siempre a Ecbatana a su toponimia evocadora, a su Oriente de ilusión, Darío apenas aprovecha de «Crimen amoris» más que algún otro detalle: "Or, le plus beau d'entre tous ces mauvais anges / Avait seize ans sous sa couronne de fleurs (...) / Il rêve, l'oeil plein de flammes et de pleurs"» (378). Como dice Mapes, "ici, comme presque toujours, Darío est un artiste trop raffiné pour tirer toute son inspiration d'une seule source, si bonne qu'elle soit» (1925: 73-74). Chasca publicó en 1956 un estudio comparativo o contrastivo entre los dos poemas, ampliado algo en la versión de 1974 que usamos, donde sostenía que «Crimen amoris» era «el modelo literario mas importante» de «El reino interior», algo que fue discutido por Fiber (1972-73: 92-95).

7. Reproduzco parte de la morosa y soberbia descripción del poderoso, delicado y malsano Satán-Eros en «Les Tentations. Ou Éros, Plutus et la Gloire» de Le Spleen de Paris, subrayando algunos de los vocablos y expresiones que, creo, selecciona Darío: "Le visage du premier Satan était d'un sexe ambigu, et il y avait aussi, dans les lignes de son corps, la mollesse des anciens Bacchus. Ses beaux yeux languissants (...), et ses lèvres entrouvertes à des cassolettes chaudes, d'où s'exhalait la bonne odeur d'une parfumerie ; et à chaque 
ajustan al modelo de belleza masculina demoniaca y decadente, de la que Darío extrae rasgos que ajusta por oposición a la belleza de las princesas prerrafaelitas. De la nueva descripción, que invierte notoriamente la orientación, la paleta y los valores estéticos y simbólicos de la anterior, sólo anoto «veneficios» con v, que no es una errata, es lo que Darío llamó uno de sus «inusitados y sugerentes escogimientos verbales» (1950: 1, 212), un sutil arcaísmo elegido por su carácter equívoco, pues significa «maleficio», precisamente lo contrario a «beneficio» con b.

Pero la psicomaquia no se resuelve en confrontación ni en triunfo, la falta de desenlace es el desenlace del poema. Esto es lo que lo distancia de la alegoría tradicional cristiana. No hay despertar ni elección consciente por parte de la princesa, quien parece no querer o no poder convertirse en lo que la normativa social llamaría un ser adulto o racional. El poema se repliega y el poeta interroga a su alma, vuelve a tratarla de «infanta» pero también de «mariposa», símbolo de lo voluble, y de "hermana de la Bella durmiente», símbolo del sueño, la inmovilidad y la eterna espera. La doble pregunta ( «iAcaso piensas en la blanca teoría? ¿Acaso/ los brillantes mancebos te atraen, mariposa?») se corresponde con las exclamaciones finales en las que el alma, en el interior de su interior, revela sus más secretos deseos, lo que no puede decir fuera del sueño: «iPrincesas, envolvedme con vuestros blancos velos!/ ¡Príncipes, estrechadme con vuestros brazos rojos!».

Una rápida digresión a partir de este abrazo final. Tradicionalmente el poema ha sido interpretado más o menos ampliamente pero siempre en el sentido que el propio Darío parece propiciar: como un símbolo de los conflictos entre el vicio y la virtud o, si se quiere, entre lo cristiano y lo pagano, lo espiritual y lo carnal, el dualismo moral generador de tensiones y neurosis que el proceso de secularización moderna empezó a hacer insostenible. Tales interpretaciones no se detenían en el hecho excepcional y algo enigmático de que Darío usara como imagen de la "depravación" pero también del deseo a figuras efébicas o de masculinidad ambigua. En cualquier caso, este es un uso que siempre cabe entender dentro de la gramática alegórica del poema, según la cual se personifica a "las virtudes" en figuras femeninas y a "los vicios" en

fois qu'il soupirait, des insectes musqués s'illuminaient, en voletant, aux ardeurs de son souffle. Autour de sa tunique de pourpre était roulé, en manière de ceinture, un serpent chatoyant qui, la tête relevée, tournait langoureusement vers lui ses yeux de braise. À cette ceinture vivante étaient suspendus, alternant avec des fioles pleines de liqueurs sinistres, de brillants couteaux (...) À ses chevilles délicates traînaient quelques anneaux d'une chaîne d'or rompue, et quand la gêne qui en résultait le forçait à baisser les yeux vers la terre, il contemplait vaniteusement les ongles de ses pieds, brillants et polis comme des pierres bien travaillées" (Baudelaire, 1968:161-162). 
figuras masculinas. Pero durante los últimos años las teorías de género y los estudios queer han puesto su foco en las transgresiones, disidencias y ambigüedades sexuales del modernismo hispánico, y a partir de aquí han tratado también de revisar o matizar la identidad masculina, hasta ahora fuera de toda duda, de Darío. En 2002 Blas Matamoro publicó un ensayo biográfico que levantó revuelo en Nicaragua, pues deja «la puerta entornada para que el uranismo entre a ocupar un discreto espacio» en el mundo dariano (201). Para él había pulsiones bisexuales en Darío y, dice, «la escena más elocuente es la que monta en 'El reino interior'», en la que el alma del poeta «finalmente sale del armario» (206). Algo después y en esta línea, Francisco Morán publicó «'Con Hugo fuerte y con Verlaine ambiguo': el Reino Interior o los peligrosos itinerarios del deseo en Rubén Darío», donde llega a la conclusión de que «el yo de Darío no puede afirmar una identidad heterosexual sin fisuras, sin fallas peligrosas» (2006: 494). La base textual y biográfica para estas hipótesis era realmente muy débil. Al menos hasta hace cuatro años, cuando Alberto Acereda (2012: 895-924) publicó unas sorprendentes cartas procedentes del archivo dariano adquirido por la Universidad Estatal de Arizona, que venían a probar una relación homosexual episódica entre Darío y Amado Nervo. Pero tras el «shock» y la polémica inmediata, y aunque la discusión sobre la autenticidad de todos los manuscritos darianos de Arizona no se ha cerrado, la razón se inclina sin duda hacia los especialistas que, como Günther Schmigalle (2012: 37-44), consideran tales cartas como una falsificación, posiblemente de algún avispado conocedor de novedades y modas críticas académicas.

Y concluyo volviendo al principio. Con Prosas profanas Darío se consagró definitivamente como maestro poético de los jóvenes de Argentina, de Hispanoamérica y algo después de España, pero no alcanzó la sanción internacional, que tanto había ansiado, y que solo podía conceder un París muy desatento aún a las literaturas periféricas. Las discusiones críticas en torno a su obra se centraban en cuestiones como su falta o no de americanismo, o como su sinceridad, en si poesías como esta, tan esteticista y culturalista, eran expresión verdadera de sentimientos e ideas, en si tras esa belleza había realmente un alma. Rodó, pese a sus reservas en tales sentidos, no se sustrajo a la tentación de hablar en Ariel de su propio «reino interior». Para los darianos confesos no había duda: «El reino interior» era belleza y también espíritu. Manuel Machado usó a modo de homenaje y continuación el título «El reino interior» para la primera sección de su libro Alma (1902), en el que también figura la sección «Museo». Pedro L. Barcia, uno de los mejores editores modernos de Prosas profanas, explica así la recurrente pero para él falsa discusión entre «lirismo auténtico» $\mathrm{y}$ «poesía de cultura»: 
En esta obra, la suya (de Darío) es una lírica refleja, que proyecta la vida profunda sentimental pero a través de situaciones, figuras y símbolos que la expresan y la embozan a un tiempo. Sus símbolos se sustentan en sentidos vitales hondos, no son mero recurso decorativo o de exornación externa. Bastaría para confirmarlo el poema que cerraba la primera edición, «El reino interior», situado intencionalmente al cabo de un libro en que el alma no parecía asomarse entre tanta exterioridad. El poema tiene un valor de posición, porque en él - a la hora de la despedida del diálogo entre poeta y lector- se revela la condición anímica del autor, pero transpuesta en la imagen, desplegada escenográficamente, de la infanta asomada a la torre contemplando el desfile contrastado de Vicios y Virtudes, sintiéndose atraída, simultáneamente, por ambos (1996: 58).

Para Darío «El reino interior» fue un poema límite, al que siguió una evolución, que no una ruptura, marcada por su establecimiento en Europa y por una profunda crisis histórica, personal y literaria. A partir de la segunda edición de Prosas profanas y más aún a partir de Cantos de vida y esperanza, la significación de «El reino interior», lo que Darío llamó su «sed de novedad» y su «delirio de arte» (1938: 121), y más aún su función estructural y autoconsagratoria que he tratado de restituir aquí, se diluyeron bastante. A partir de entonces los poemas de cierre y apertura pasaron a ser definitivamente «Yo persigo una forma», «Yo soy aquel que ayer no más decía» y «Lo fatal». Pero en estos libros y en estos poemas de total madurez, cuando Darío ya no tiene que medirse con nadie sino consigo mismo, cuando cita menos la poesía de otros que la suya propia, cuando ésta se va haciendo más inconfundiblemente personal y menos refleja de modelos europeos, no deja de hablar de su «Divina Psiquis» ni de recordar y explicar que poemas como «El reino interior» eran «carne viva», la expresión sincera de un «alma joven», de una «sed de ilusiones infinita».

\section{Bibliografía citada}

ACEREDA, A., «"Nuestro más profundo y sublime secreto": los amores transgresores entre Rubén Darío y Amado Nervo», Bulletin of Spanish Studies, 89, 6 (2012), pp. 895-924.

Baudelaire, C., Petits Poëmes en prose (Le Spleen de Paris), Euvres complètes, ed. M. A. Ruff, Paris, Seuil, 1968.

BARCIA, P. L., «Estudio preliminar. Prosas profanas, breviario poético modernista», en Darío, R., Prosas profanas y otros poemas, Buenos Aires, Embajada de Nicaragua, 1996, pp. 13-68.

CAlinescu, M., Cinco caras de la modernidad. Modernismo, vanguardia, decadencia, kitsch, posmodernismo, Madrid, Tecnos, 1991. 
CHASCA, E. de: «El Reino Interior de Rubén Darío y Crimen Amoris de Verlaine», en Porrata y Santana, Antología comentada del modernismo, California State University, Explicación de Textos Literarios, 1974, pp. 277-288.

DARíO, R., Escritos inéditos, ed. E. K. Mapes, New York, Instituto de las Españas, 1938.

- Obras completas, 5 vols., Madrid, Afrodisio Aguado, 1950-1955.

- Crónicas desconocidas, ed. G. Schmigalle, Berlín/Managua, Tranvía-Verlag Water Frey, 2006.

- Poesías completas, ed. A. Méndez Plancarte y A. Oliver Belmás, Madrid, Aguilar, 1967.

- Obra poética, ed. J. C. Rovira con la colaboración de S. Galindo, Madrid, Fundación José Antonio de Castro, Biblioteca Castro, 2011.

- Los Raros, ed. G. Schmigalle, Estudio preliminar de J. E. Arellano, Berlin, edition tranvía - Verlag Water Frey, 2015.

FEIN, John W., «Eugenio de Castro and the Introduction of the Modernismo in Spain», PMLA, LXXIII, 5 (1958), 555-561.

— «Una fuente portuguesa de "El reino interior" », Revista Iberoamericana, XXXIII, 64 (1967), pp. 359-365.

FIBER, L. A., «Rubén Darío's Debt to Paul Verlaine in 'El reino interior'», Romance Notes, XIV (1972-73), pp. 92-95.

LóPez EstradA, F., Rubén Darío y la Edad Media, Barcelona, Planeta, 1971.

— «Más sobre el prerrafaelismo de Rubén Darío: el ensayo sobre la pintora inglesa D. Morgan», Anales de Literatura Hispanoamericana, 7 (1978), pp. 191-203.

LOZANO, C., La influencia de Rubén Darío en España, León, Nicaragua, Universidad Autónoma de Nicaragua, 1978.

MAPES, E. K., Linfluence française dans l'oeuvre de Rubén Darío, Paris, Edouard Champion, 1925.

Marasso, A., Rubén Darío y su creación poética, Buenos Aires, Kapelusz, 1954.

Matamoro, B., Rubén Darío, Madrid, Espasa Calpe, 2002.

Mejía SÁnchez, E., «Criterios de esta edición», en Darío, R., Poesía, Caracas, Ayacucho, 1985, pp. LIII-LXXXIX.

Monguió, L., «En torno a "El Reino Interior", de Rubén Darío», en Notas y estudios de literatura peruana y americana, México, Libros de México, 1972, pp. 189-199.

MorÁN, F., "Con Hugo fuerte y con Verlaine ambiguo": el Reino Interior o los peligrosos itinerarios del deseo en Rubén Darío», Revista Iberomericana, LXXII, 215-216 (abril-septiembre 2006), pp. 481-495.

Nordau, M., Degeneración, Traducción de N. Salmerón, 2 tomos, Madrid, Fernando Fe, 1902 (Reimpresión facsímil, Pamplona, Analecta, 2004).

Rodó, J. E., La Vida Nueva (II). Rubén Darío, en Obras completas, ed. E. Rodríguez Monegal, Madrid, Aguilar, 1967. 
RULL, E., «El símbolo de Psique en la poesía de Rubén Darío», Revista de literatura, 53-54 (1965), pp. 33-50.

— «Composición y fuentes de La princesa Psiquia de Rubén Darío», en C. Cuevas García (ed.), Rubén Darío y el arte de la prosa. Ensayo, retratos y alegorías, Málaga, Publicaciones del Congreso de Literatura Española Contemporánea, 1998, pp. 323-336.

Salinas, P. (1948), La poesía de Rubén Darío. Ensayo sobre el tema y los temas del poeta, Barcelona, Seix Barral, 1975.

Schmigalle, G., «El poeta de Nicaragua y el gran fraude de Arizona», Temas Nicaragüenses, 56 (diciembre 2012), pp. 37-44.

Verlaine, P., Jadis et Naguère, Oeuvres poétiques complètes, ed. Y. G. De Dantec y J. Borel, Paris, Gallimard, 1962.

Zuleta, I. M., «Introducción» y «Apéndices», en Darío, R., Prosas profanas y otros poemas, Madrid, Castalia, 1987, pp. 9-82 y 179-219. 